\title{
SCS426 Venice: new apple cultivar with glomerella leaf spot resistance and picking time in March
}

Crop Breeding and Applied Biotechnology 19(4), 481-486, 2019 Brazilian Society of Plant Breeding. Printed in Brazil http://dx.doi.org/10.1590/198470332019v19n4c69

\section{Frederico Denardi ${ }^{1 *}$, Marcus Vinícius Kvitschal ${ }^{1}$, Maraisa Crestani Hawerroth ${ }^{1}$ and Luiz Carlos Argenta ${ }^{1}$}

\begin{abstract}
SCS426 Venice was developed by hybridization between Epagri 404-Imperatriz ( + ) and Epagri 406-Baronesa ( $\hat{)})$, performed at the Epagri Experimental Station in Caçador, SC, Brazil, in 2001. It requires less winter chilling than 'Gala' and 'Fuji' traditional clones, whose fruit is picked in March. It is resistant to glomerella leaf spot.
\end{abstract}

Keywords: Malus x domestica Borkh., chilling requirement, harvest window.

\section{INTRODUCTION}

Apple (Malus $x$ domestica Borkh.) is the second most produced temperatezone fruit in Brazil, with production of around 1.3 million tons, and the South region of Brazil is responsible for $98 \%$ of total production (BRDE 2011, FAOSTAT 2017). However, a restricted number of cultivars have been grown commercially in Brazil. Currently, more than 90\% of apple production in Brazil is 'Gala' and 'Fuji' clones picked in February and April, respectively (Pérès 2009), with a high concentration of ripening in those two months, augmenting the difficulties for harvesting and processing the fruit at storage facilities at those times. Growers have been using many technologies to extend the harvest window of Gala, due to lack of another cultivar with a harvest window in March (Gonçalves et al. 2017). Invariably, these technologies generate additional production costs.

Even though Gala and Fuji apple clones are well known references for flavor and have wide acceptance among Brazilian consumers, they also have important limitations for the apple production chain in southern Brazil. Gala and Fuji cultivars are overly susceptible to many serious pathogens. Chemical control of these pathogens constitutes one of the main production costs for Brazilian apples. Currently, the main plant health problem that generates costs in apple orchards is glomerella leaf spot (Colletotrichum spp.), a disease that severely attacks the Gala standard and its traditional colored-fruit mutations. Control of this pathogen requires special attention from growers and, generally, high rates of pesticide application. Thus, the incorporation of genetic resistance to local pathogens has been the cheapest and the most efficient approach for control of diseases and pests, and has been used worldwide in apple breeding since the middle of the twentieth century (Janick et al. 1996).

*Corresponding author: E-mail: denardi.frederico@gmail.com (iD) ORCID: 0000000266724293

Received: 24 March 2019 Accepted: 14 August 2019

The traditional Gala and Fuji clones also have limitations regarding climate adaptation to southern Brazil (Petri et al. 2011) as they were developed for colder

${ }^{1}$ Epagri, Estação Experimental de Caçador, Caçador, SC, 89.501-032, Brazil 
areas in other countries. Therefore, in Brazil, the trees of these cultivars must be treated with chemicals to compensate for deficient chilling and to stimulate breaking of bud dormancy. This treatment represents additional production costs, as well as contamination risks for workers and the environment.

The Apple Breeding Program of Epagri aims to offer fruit growers new cultivars that are better adapted to the local climate and that have better resistance to prevalent diseases. It has already developed promising cultivars (Denardi et al. 2015a). These characteristics, that have been developed, assist yield performance of the orchards and fruit quality over time, and they help reduce production costs, meeting the expectations of apple growers.

The SCS426 Venice apple cultivar is a new option for harvest in the gap between the picking time of traditional Gala and Fuji clones. It also carries agronomic characteristics related to high yield potential and good climate adaptation to the main apple production regions of southern Brazil. It has high genetic resistance to glomerella leaf spot disease, produces red-colored fruit with high quality on flesh texture, and allows storability to be extended to that of Fuji apples. Its sweet, sub-acid flavor satisfactorily meets Brazilian consumer expectations.

\section{Origin and Breeding Methodology}

The composition of the parental line that gave rise to 'SCS426 Venice' involves the cultivars Epagri 404-Imperatriz ( $(+)$ and Epagri 406-Baronesa ( $\widehat{\jmath})$, and is a granddaughter of 'Gala' and of 'Fuji', as represented in Figure 1. It was developed with the main objective of incorporating low chilling requirements (for good local climate adaptation) and high resistance to Glomerella Leaf Spot - traits found in both parents. Further aims were high organoleptic quality and good fruit storability, characteristics of 'Epagri 406-Baronesa'. The initial steps for developing the 1400 seedlings of this segregating population, considering hybridization, $F_{1}$ seed harvest, and germination, and initial cultivation of the hybrid population from which 'SCS426 Venice' was selected, were performed according to Denardi et al. (2013). The initial evaluations for disease resistance, early fruit bearing and subsequent evaluations of yield potential, local climate adaptation, and fruit quality likewise followed the methodology described by these authors. Glomerella Leaf Spot resistance was identified by artificial inoculation of the disease in the laboratory, according to the methodology described by Furlan et al. (2010).

The selections that stand out for the established agronomic characteristics and for genetic resistance to the main diseases were multiplied on the G.814 semi-dwarf commercial rootstock. This was followed by advanced evaluations at the Epagri Experimental Station of Caçador (EECd) and in the municipality of Fraiburgo (lat $27^{\circ} 03^{\prime} 47^{\prime \prime} \mathrm{S}$, long $50^{\circ}$

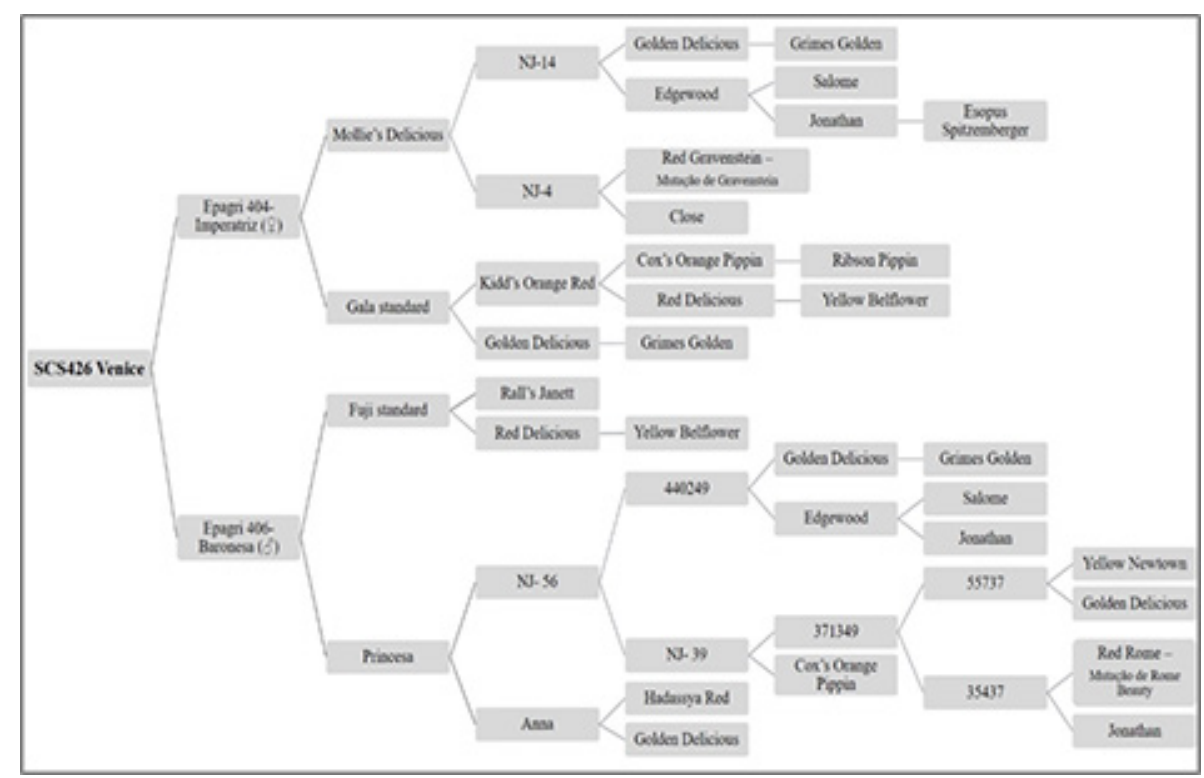

Figure 1. Pedigree of the apple cultivar SCS426 Venice. Occasional absence of the second parent is due to lack of information reported in the available literature. 
52' 54" W, alt $1047 \mathrm{~m}$ asl), with an average of 1,112 Chilling Units, according to the modified North Carolina Model), which is located in an important apple production region in the midwestern part of the state of Santa Catarina. These studies were carried out under a randomized block experimental design, with four replications of four trees per plot, at a spacing of $1.8 \mathrm{~m}$ between plants and $4.5 \mathrm{~m}$ between rows (1,235 plants per hectare), including the cultivars Galaxy and Fuji Suprema as controls. In this phase, the vigor and climate adaptation of the plants, the phenology of flowering and fruit maturation, fruit weight, and fruit yield were evaluated following the methodology described by Denardi et al. (2013). In this step, apple maturity and fruit quality were evaluated according to methodologies adopted by Martin et al. (2018). Some details of the apple cultivar SCS426 Venice in relation to the tree, fruit, and flowers are shown (Figure 2).

\section{Plant vigor, climate adaptation, flowering phenology and early fruit bearing}

SCS426 Venice is a vigorous cultivar, more vigorous than 'Galaxy' and 'Fuji Suprema', based on evaluation of the trunk cross sectional area - TCSA (Table 1). Evaluations for local climate adaptation indicate that this apple cultivar has lower chilling requirements than 'Galaxy' and 'Fuji Suprema' and, consequently, sprouting and flowering occur around a week before 'Galaxy' (Table 2).

Studies related to blooming intensity in the second year after planting on young trees still in structural formation suggest that SCS426 Venice is an earlier cultivar for commercial production than 'Galaxy' and 'Fuji Suprema', since this cultivar has more floral structures. This characteristic contributes to a more rapid return on the capital invested in orchard

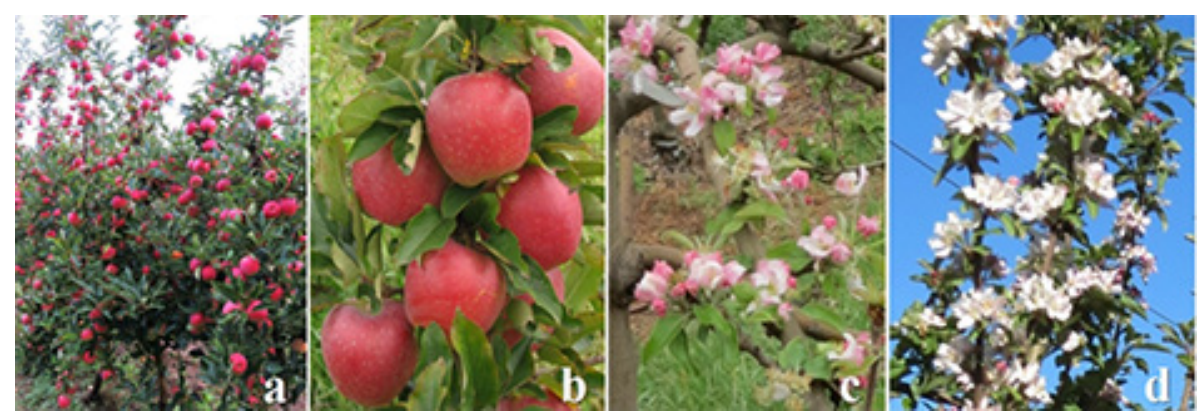

Figure 2. Pictures of the apple cultivar SCS426 Venice. a) trees with high fruit load on Marubakaido/inter stem of M.9 rootstocks; b) fruit in detail; c) flowers at balloon stage; d) flowers at full bloom stage.

Table 1. Agronomic characteristics of the apple cultivars SCS426 Venice, Galaxy, and Fuji Suprema grafted on the G.814 semi-dwarf rootstock in different seasons in the municipality of Fraiburgo, in the midwestern part of the state of Santa Catarina, Brazil

\begin{tabular}{|c|c|c|c|c|c|c|c|c|c|}
\hline \multicolumn{10}{|c|}{ Data } \\
\hline \multirow{2}{*}{ Cultivar } & \multirow{2}{*}{$\begin{array}{l}\mathrm{TCSA}^{*} \\
\left(\mathrm{~cm}^{2}\right)\end{array}$} & \multicolumn{5}{|c|}{ Yield in each season $^{* *}\left(\mathrm{~kg} \mathrm{plant}^{-1}\right)$} & \multirow{2}{*}{$\begin{array}{l}\text { Cumulative yield } \\
\left(\mathrm{kg} \mathrm{plant}^{-1}\right)\end{array}$} & \multirow{2}{*}{$\begin{array}{c}\text { Average yield } \\
\left(\text { kg plant }^{-1}\right)\end{array}$} & \multirow{2}{*}{$\begin{array}{l}\text { Average fruit } \\
\text { weight } \\
\text { (g) }\end{array}$} \\
\hline & & $2011 / 12$ & $2012 / 13$ & $2013 / 14$ & \multicolumn{2}{|c|}{$2014 / 15$} & & & \\
\hline $\begin{array}{l}\text { SCS426 } \\
\text { Venice }\end{array}$ & $17.00 \mathrm{a}$ & B 16.83 a & C 5.75 a & A 37.06 a & \multicolumn{2}{|c|}{ C $10.56 \mathrm{~b}$} & $62.75 \mathrm{a}$ & $17.51 \mathrm{a}$ & $124.97 \mathrm{~b}$ \\
\hline Galaxy & $10.72 \mathrm{c}$ & B 4.01 b & В 10.50 a & B 9.75 b & \multicolumn{2}{|c|}{ A 21.45 a } & $45.25 \mathrm{~b}$ & $11.36 \mathrm{~b}$ & $121.44 \mathrm{~b}$ \\
\hline Fuji Suprema & $15.00 \mathrm{~b}$ & B $4.14 \mathrm{~b}$ & B $11.75 \mathrm{a}$ & B $8.24 \mathrm{~b}$ & \multicolumn{2}{|c|}{ A 18.53 a } & $42.36 \mathrm{~b}$ & $10.59 \mathrm{~b}$ & $152.74 \mathrm{a}$ \\
\hline Cultivar & \multicolumn{2}{|c|}{$\begin{array}{l}\text { Blooming period }{ }^{* * *} \\
\text { (Beginning to end) }\end{array}$} & $\begin{array}{c}\text { Fruit ripening }^{* * *} \\
\text { (Initial) }\end{array}$ & \multicolumn{2}{|c|}{$\begin{array}{l}\text { Climate adaptation } \\
\text { in midwestern } S^{1{ }^{* *}}\end{array}$} & Scab & Mildew & Bitter rot & $\begin{array}{c}\text { Glomerella Leaf } \\
\text { Spot }\end{array}$ \\
\hline $\begin{array}{l}\text { SCS426 } \\
\text { Venice }\end{array}$ & $14 / 0 s$ & 28/09 & 05/03 & & & MR & MR & MR & $\mathrm{R}$ \\
\hline Galaxy & $22 / 0 s$ & 04/10 & 28/01 & & & $S$ & $\mathrm{~S}$ & $S$ & $S$ \\
\hline Fuji Suprema & $17 / 0 s$ & $01 / 10$ & $28 / 03$ & & & $S$ & MR & $S$ & $\mathrm{R}$ \\
\hline
\end{tabular}

Averages followed by the same uppercase letter in the row and lowercase letter in the column do not differ from each other by the Scott-Knott test at $5 \%$ error probability. Analyses performed using the Sisvar software (Ferreira 2011). "TCSA: Trunk cross sectional area measured at $5 \mathrm{~cm}$ above the grafting point for the $2012 / 2013$ growing season. ${ }^{* *}$ Data collected over four seasons (from 2011/2012 to 2014/2015). ${ }^{* * *}$ Data collected over six seasons (from $2009 / 2010$ to $2014 / 2015$ ). ${ }^{1}$ Numerical scale, where 1 corresponds to sprouting of only the apical buds of branches and 5 represents the sprouting of all buds (vegetative and floriferous), in response to chemical treatment to overcome the dormancy of buds with $3.5 \%$ mineral oil and $0.7 \%$ hydrogenated cyanamide. R: resistant, MR: moderately resistant, S: susceptible. 
planting, and even to augmenting the cumulative yield over time (Table 1). 'SCS426 Venice' also has strong capacity for differentiation of flower buds on spurs and brindles, resulting in intensive blooming.

\section{Fruit yield}

Yield results obtained over four consecutive seasons indicate that 'SCS426 Venice' produced significantly more than the controls 'Galaxy' and 'Fuji Suprema' in the first season (Table 1). However, for the following seasons, there was variation in the yield of 'SCS426 Venice'. This variable behavior of 'SCS426 Venice' is an indication of biennial bearing vulnerability, resulting from insufficient fruit thinning in the first and the third crop seasons. The thinning procedure in this experiment was conducted according to technical recommendations for 'Galaxy' and 'Fuji Suprema', but it was insufficient for 'SCS426 Venice'. Thus, the cultivar SCS426 Venice requires more severe thinning than that applied to traditional Gala and Fuji clones, at least in the first two crop seasons after the beginning of fruit production. The thinning recommendation for 'SCS426 Venice' must still be defined, based on future specific trials.

Nevertheless, the cumulative and the average yield of 'SCS426 Venice' (62.75 and $17.51 \mathrm{~kg} \mathrm{plant}^{-1}$, respectively), considering the four seasons evaluated, were statistically higher than the yields of the controls 'Galaxy' ( 45.25 and 11.36 $\mathrm{kg} \mathrm{plant}^{-1}$, respectively) and 'Fuji Suprema' (42.36 and $10.59 \mathrm{~kg} \mathrm{plant}^{-1}$, respectively) (Table 1 ).

\section{Fruit characteristics}

'SCS426 Venice' fruit has red-blushed skin, a little darker than that of 'Fuji Suprema' fruit, without stripes, and bi-color default with a yellowish background. The russeting disorder is unusual (infrequent/rare) and, when present, it is restricted to the stalk cavity. The fruit has a round-conical shape and uniform caliber, which suggest good adaptation of the cultivar to local climate. The 'SCS426 Venice' fruit mass (124.97 g) is similar to 'Galaxy' fruit mass (121.44 g) and significantly smaller than 'Fuji Suprema' fruit mass (152.74 g). The flesh has a white-cream color and is expressively crispy and very juicy. The fruit of 'SCS426 Venice' normally ripens during the first half of March, at the same time as 'Golden Delicious' and 'Daiane', which corresponds to the gap between the picking time of 'Galaxy' and 'Fuji Suprema' in the midwestern part of the state of Santa Catarina (Table 2). Maturity indices for 'SCS426 Venice' apples intended for long-term storage is 17 to $18 \mathrm{lb}$. for firmness, 3.0 to 5.5 for starch index (scale 1 to 9), $11.8 \%$ to $12.5 \%$ for soluble solids content (SSC), and $0.355 \%$ titratable acidity, according to evaluations made by Betinelli et al. (2017). The 'SCS426 Venice' fruit is firmer than 'Fuji Suprema' fruit when both are harvested with a similar starch index and SSC (Figure 3).

\section{Disease resistance}

'SCS426 Venice' carries genetic resistance to Glomerella Leaf Spot (Table 1). Since this is currently the main apple disease in southern Brazil, this resistance should allow reduction in production costs for plant disease control compared to the production costs of 'Gala' when adopting traditional clones, since they are very susceptible to this disease. In previous evaluations, 'SCS426 Venice' showed also higher resistance to scab, powdery mildew, and bitter rot than the control 'Galaxy' (data not shown).

\section{Fruit storability}

The storage potential of 'SCS426 Venice' fruit was assessed by comparing it to that of 'Fuji Suprema' fruit. 'SCS426 Venice' and 'Fuji Suprema' were harvested from the same experimental orchard at 170 days and 195 days after full bloom, respectively, in 2012. The fruit was cooled to $1^{\circ} \mathrm{C}$ at 36 hours after harvest, kept in regular cold air for 2 weeks, and then stored in a controlled atmosphere - $\mathrm{CA}\left(1.5 \mathrm{kPa}\right.$ of $\mathrm{O}_{2}$ and $2.0 \mathrm{kPa}$ of $\mathrm{CO}_{2}$ at $0.7 \pm 0.5 \stackrel{\circ}{ } \mathrm{C}$ and $\mathrm{RH}$ of $\left.92 \pm 3 \%\right)$. The starch index (5.0 for 'SCS426 Venice' and 5.4 for 'Fuji Suprema', on a scale of 1-9) and soluble solids content - SSC (11.3\% for 'SCS426 Venice' and 11.6\% for 'Fuji Suprema') were not significantly different between the two cultivars at harvest time.

There was no interaction $(p<0.05)$ between cultivars and storage time for fruit firmness, acidity, and SSC. Therefore, rates of firmness and acidity losses and SSC changes over eight months of storage were the same in 'SCS426 Venice' and 'Fuji Suprema' fruit, and the differences between 'SCS426 Venice' and 'Fuji Suprema' fruit at harvest for flesh firmness and acidity remain similar over the eight months storage period (Figure 3). Fruit of 'SCS426 Venice' was not affected by $\mathrm{CO}_{2}$ injury and superficial scald over the eight months of storage in a controlled atmosphere. As expected, symptoms 
of $\mathrm{CO}_{2}$ injury and superficial scald were noticeable in 'Fuji Suprema' fruit from the 2nd and 4th month of storage on, respectively. Symptoms of superficial scald developed in one of the two years of the study on 'SCS426 Venice' after six months of storage in regular air (Martin et al. 2018). Thus, the CA storage condition prevents superficial scald on 'SCS426 Venice' and less energy to scrub $\mathrm{CO}_{2}$ is demanded to store fruit of this cultivar in a CA. Low calcium related disorders have also not been detected in fruit of 'SCS426 Venice'. Development of fungal decay on 'SCS426 Venice' apples steadily increased in a linear manner over the eight months of storage, but at a slower rate than in 'Fuji' (Figure 3). The main decay symptom in 'SCS426 Venice' apples was caused by Penicillium sp.

The storage potential of apple fruit is usually limited by the development of physiological disorders, fungal decay, fruit softening, and loss of flavor (Harker et al. 2003, Harker et al. 2008). Most consumers prefer apples with high flesh firmness ( $\geq 14 \mathrm{lb}$ ) and high SSC, yet some prefer fruit with a high SSC/acidity ratio and others prefer a low SSC/acidity ratio (Harker et al. 2008). The risk of apple fruit rejection by consumers due to low sweetness is greater when SSC is below $12 \%$ (Harker et al. 2003). Therefore, based on postharvest susceptibility to physiological disorders, rates of fruit softening, and changes in SSC, the storage potential of 'SCS426 Venice' apple fruit in a CA is greater than eight months. The development of fungal decay appears to be the limiting factor for long-term storage of 'SCS426 Venice' apples in a CA.

\section{Pollination}

Apple (Malus $x$ domestica, Borkh.) has a biochemical mechanism in its floral structure that prevents self-pollination, inducing gametophytic incompatibility whenever the genes (S alleles) of the pollen tube and the stigma are identical (Kasajima et al. 2017). 'SCS426 Venice' also seems to have this biological process, as confirmed by previous evaluations, preventing self-pollination. With the objective of ensuring good fruit production, studies have been conducted at the Epagri Experimental Station of Caçador aiming to identify compatible and efficient pollinizers for 'SCS426 Venice' (under experimental code M-29/08) (Denardi et al. 2015b). According to these results, good efficiency for pollinizing 'SCS426 Venice' was obtained with the commercial cultivar SCS425 Luiza (experimental code M-15/07) and with the pollinizer cultivars SCS431 Felix 1, SCS433 Felix 3, SCS434 Felix 4, and SCS438 Felix 9 (under experimental codes 140/228, 140/191, 140/126, and 135/140, respectively). Blooming of all these genotypes coincides well with 'SCS426 Venice'. The blooming of 'SCS425 Luiza' coincides well with 'SCS426 Venice' and also has a high flowering index. 'SCS425 Luiza' bears fruit early, similar to 'SCS426 Venice', providing early yields for both. It also has fruit of high quality for flavor, texture, and skin-finish.

\section{Vegetative material for grafting}

As this apple cultivar is under protected Plant Variety Rights in Brazil in the Serviço Nacional de Proteção de Cultivares - SNPC (National Cultivar Protection Service), grafted trees of 'SCS426 Venice' and its pollinizers should be acquired directly from nurserymen licensed and authorized by Epagri. Additional information can be obtained by contacting the Epagri Experimental Station of Caçador at telephone +55 (049) 35616800 . 


\section{ACKNOWLEDGMENTS}

Our thanks to the Fischer S/A Company for their kind permission and logistical support for conducting the studies on its property in Fraiburgo, SC, in the advanced phase of the field tests; to FAPESC (Fundação de Amparo à Pesquisa no Estado de Santa Catarina); to ABPM (Associação Brasileira de Produtores de Maçã); and to Emprapa Uva e Vinho through the AppleClim Project, for financial support during development of 'SCS426 Venice'.

\section{REFERENCES}

Betinelli KS, De Martin MS, Argenta LC, Amarante CVT and Denardi F (2017) Estádio de maturação para colheita de maçãs 'SCS426 Venice'. Revista Agropecuária Catarinense 30: 57-62.

BRDE - Banco Regional de Desenvolvimento do Extremo Sul. Superintendência de Planejamento (2011) Cadeia produtiva da maçã no Brasil: limitações e potencialidades. BRDE, Porto Alegre, 44p.

Denardi F, Camilo AP and Kvitschal MV (2013) SCS417 Monalisa: cultivar de macieira com boa adaptação climática no Sul do Brasil e resistência múltipla a doenças e pragas. Revista Agropecuária Catarinense 26: 56-62.

Denardi F, Kvitschal MV and Hawerroth MC (2015a) SCS425 Luiza, SCS426 Venice e SCS427 Elenise: novas cultivares de macieira da Epagri para o Sul do Brasil. In Anais do encontro nacional sobre fruticultura de clima temperado. Epagri, Caçador, p. 96-103.

Denardi F, Kvitschal MV, Hawerroth MC, Yoshikawa ER, Brancher TL (2015b) Avaliação de genótipos polinizadores da seleção de macieira M-29/08. In Anais do encontro nacional sobre fruticultura de clima temperado. Epagri, Caçador, p. 155.

FAOSTAT - Food and Agriculture Organization of The United Nations data (2017) Production/Crops. Available at: <http://www.fao.org/faostat/ en/\#data/QC $>$. Accessed on January 22, 2019.

Ferreira DF (2011) Sisvar: a computer statistical analysis system. Ciência e Agrotecnologia 35: 1039-1042.

Furlan CRC, Dantas ACM, Denardi F, Becker WF and Mantovani A (2010)
Resistência genética dos acessos do Banco de Germoplasma de Macieira da Epagri à mancha foliar de glomerella (Colletotrichum gloeosporioides). Revista Brasileira de Fruticultura 32: 507-514.

Gonçalves MW, Argenta LC and Martin MS (2017) Maturity and quality of apple fruits during the harvest period at apple industry. Revista Brasileira de Fruticultura 39: 825-835.

Harker FR, Gunson FA and Jaeger SR (2003) The case of fruit quality: an interpretative review of consumer attitudes and preferences for apples. Postharvest Biology and Technology 28: 333-347.

Harker FR, Kupferman EM, Marin AB, Gunson FA and Triggs CM (2008) Eating quality standards for apples based on consumer preferences. Postharvest Biology and Technology 50: 70-78.

Janick J, Cummins JN, Brown SK and Hemmat M (1996) Apples. In Janick $J$ and Moore JN (eds) Fruit breeding, v.1 - Tree and tropical fruits. John Wiley \& Sons, New York, p. 1-77.

Kasajima I, Kikuchi T and Yoshikawa N (2017) Rapid identification of apple (Malusx domestica Borkh.) S alleles using sequencing-based DNA marker APPLid. Plant Biotechnology 34: 97-106.

Martin MS, Betinelli KS, Argenta LC, Steffens CA, Talamini CV and Kvitschal MC (2018) Storage potential of 'SCS426 Venice' apples under different storage technologies. Revista Brasileira de Fruticultura 40: 1-10.

Pérès PN (2009) O mercado mundial e nacional de maçã. In Anais do encontro nacional sobre fruticultura de clima temperado. Epagri, Caçador, p. 117-126.

Petri JL, Leite GB, Couto M and Francescatto P (2011) Avanços na cultura da macieira no Brasil. Revista Brasileira de Fruticultura 33: 48-56.

(cc) EY This is an Open Access article distributed under the terms of the Creative Commons Attribution License, which permits unrestricted use, distribution, and reproduction in any medium, provided the original work is properly cited. 